\title{
Morphometric Analysis of Daluaghat Drainage basin in Giridih District, Jharkhand, India
}

\author{
Sumitra Mandi ${ }^{1}$, Kalicharan Soren ${ }^{2}$ \\ ${ }^{1}$ Assistant Teacher, Birendranagar High School, Hooghly - 712102 (W.B.) India \\ ${ }^{2}$ Lab.attendent, School of Water Resource Engg. Jadavpur University Kol -700032(W.B.) India
}

\begin{abstract}
The word morphometry sanity the measurements and analysis of outward appearance and its properties. In perspective of geomorphology which is science of landforms it is apprehensive with the different geometrical aspects of the landforms. Morphometric analysis of Daluaghat basin was conceded.The basin morphometric parameters such as linear and aerial aspects of the river basin were determined and computed. The parameters considered for analysis are stream length, bifurcation ratio, drainage density, stream frequency, Drainage texture, form factor circularity ratio, elongation ratio, compactness ratio etc. The Daluaghat basin has a dendritic to parallel drainage pattern. It is the 5th order drainage basin. Dendritic drainage pattern in the area reveals that the area developed of homogeneous rock material, which is structurally undisturbed. Logarithm of number of stream vs stream order and length of stream segment vs stream order were computed in the basin area.
\end{abstract}

Keywords: Daluaghat basin, Morphometric parameters, Landforms, Dendritic drainage pattern.

\section{Introduction}

Drainage basins should be the study area for the enhanced understanding of the hydrologic system. The most favorable and sustainable development of the resource is requirement so that it is assessed realistically to stay away from any upcoming problems concerning its qualitative and quantitative accessibility. About $70 \%$ of population in India is dependent on agriculture, directly or indirectly. India has different geographical features and diverse climates. Morphometric analysis requires measurement of linear features, gradient of channel network and contributory ground slopes of the drainage basin (Nautiyal, 1994). The morphometric characteristics of various basins have been studied by many scientists using conventional (Horton,1945, Strahler,1957) and Remote sensing an GIS methods (Nag,1998;Srinivasa,2004; Chopraetal,2005;Nookaratram et al 2005; Thakkar et al.2007; Bhatt et al. 2007; Kar et al. 2009; Rao et al. 2010; S. Dutta et al 2012).

\section{Location of the Study Area}

The Daluaghat river basin bounded between latitude $24^{\circ} 18^{\prime}$ $\mathrm{N}$ to $24^{\circ} 23^{\prime} \mathrm{N}$. and longitude $86^{\circ} 23^{\prime} \mathrm{E}$ to $86^{\circ} 27^{\prime} \mathrm{E}$ in Survey of India Toposheet number $72 \mathrm{~L} / 8$ and having area of about $46.02 \mathrm{Km}^{2}$ ( Fig. 1). This is a tributary of BarakarRiver flowing along the left bank of Barakar River. The entire Basin is placed in the Lower Hazaribagh Plateau. The study area has a stunning climate. For five to six months of the year, from October onward the days are sunny and refreshing. The mean temperature in December is $23^{\circ} \mathrm{C}$. The nights are cold and temperatures in winter may fall below freezing point in many places. In April and May being hottest when temperature rises up to $47^{\circ} \mathrm{C}$ but it is very dry and not oppressive as in the neighboring plains.

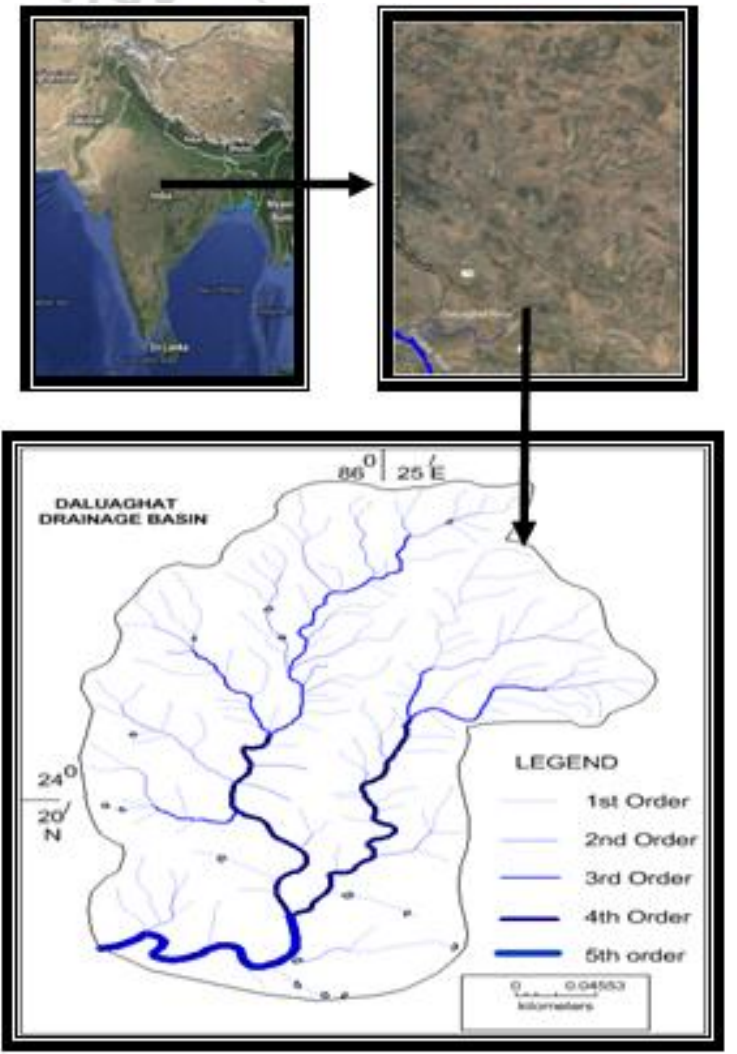

Figure 1: Location of study area

The rainy season (June to September) is pleasurable. The Chotanagpur Plateau receives an annual average rainfall of around 1,400 millimeters (55 in), which is less than the rain forested areas of much of India and almost all of it in the monsoon months between June and August. In the present paper the authors had completed an try to morphometric analysis of Daluaghat river basin 


\section{International Journal of Science and Research (IJSR) \\ ISSN (Online): 2319-7064}

Index Copernicus Value (2013): 6.14 | Impact Factor (2015): 6.391

\section{Methods \& techniques}

The Survey of India Toposheet number is $72 \mathrm{~L} / 8$ on the scale of 1: 50,000 were used for the present study. Stream ordering method as suggested by the Strahler has been in use. The different morphometric parameters have been calculated by using formulae.

\section{Results and Discussions}

\section{Computation of Morphometric Parameters}

The morphometric parameters can be generally classified into the three categories:

4.1 Linear aspects of the drainage network.

4.2 Aerial aspects of the drainage network.

4.3 Relief aspects of the drainage network.

\subsection{Linear aspects of the drainage network}

\subsubsection{Stream Order $(\mathrm{Nu})$}

In the drainage basin analysis the first step is to find out the stream orders. In the present Study, the channel segment of the drainage basin has been ranked according to Strahler's stream ordering system. According to Strahler [2] the smallest fingertip tributaries are elected as order 1 . Where two first order channels join, a channel segment of order 2 is formed; Where two of orders 2 join, a segment of order 3 is formed; And so forth. The trunk stream through which all discharge of water and sediment passes is therefore the stream segment of highest order. The study area is a 5th order drainage basin. The total numbers of 155 streams were identified of which 123 are 1st order streams, 24 are 2 nd order, 5 are 3 rd order, 2 in 4th order, 1 in 5th order streams (Table1). Drainage patterns of stream network from the basin have been observed as mainly dendritic type which indicates the homogeneity in texture and lack of structural control.

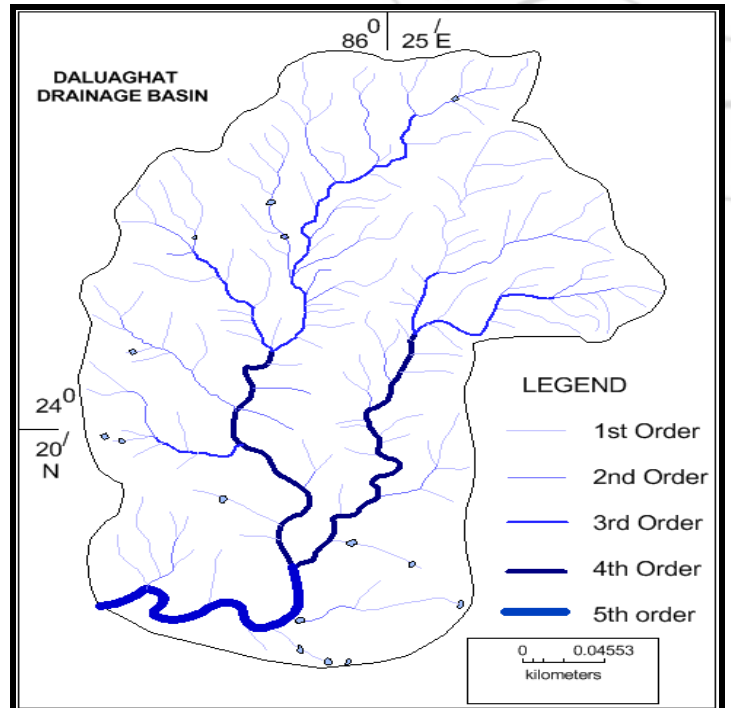

Figure 2: Stream Ordering of Daluaghat Drainage Basin (Source: SOI Topographical Map 72L/8)

\subsubsection{Bifurcation ratio $(\mathrm{Rb})$}

Bifurcation ratio is related to the branching pattern of a drainage network [3]. It is a dimensionless property and shows only a small variation for different regions with different environments except where powerful geological control dominates[2].Values of $\mathrm{Rb}$ typically range from the theoretical minimum of 3 to 5 for basins in which the geologic structures do not warp the drainage pattern[2].

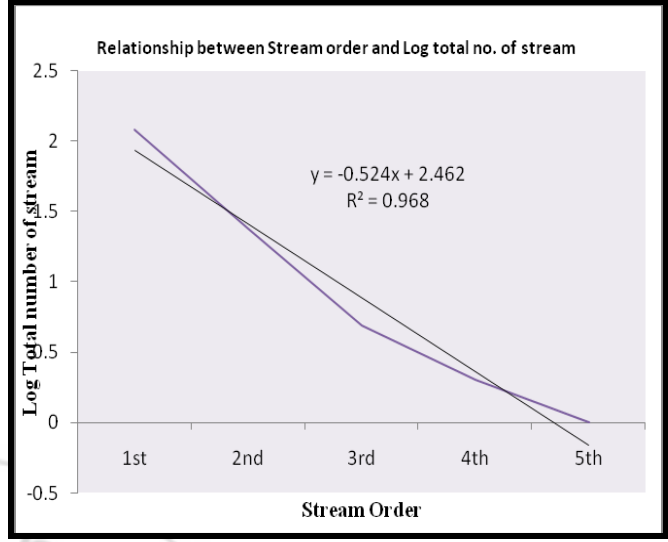

Figure 3: Relationship between stream Order and log Total number of Stream

From the Table1, it is understandable that the bifurcation ratio values for the Daluaghat drainage basin vary from 2.0 to 5.125 with the mean bifurcation ratio of 3.61 . The highest $\mathrm{Rb} 5.125$ is found between 1 st and 2 nd order.

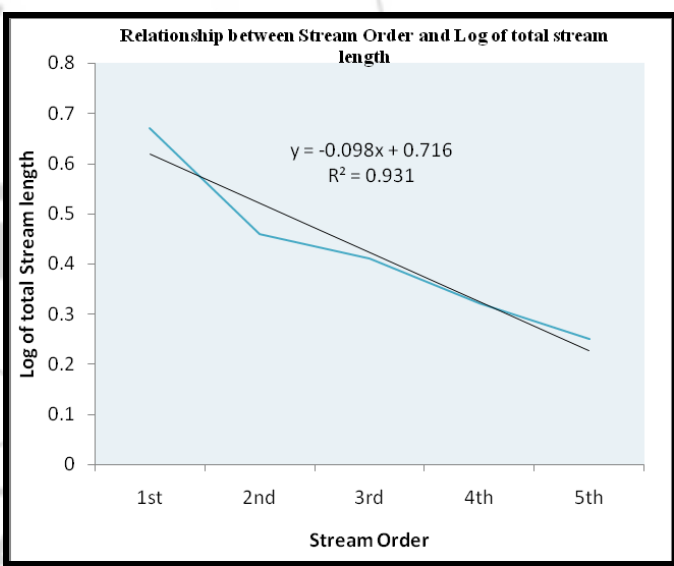

Figure 4: Relationship between stream Order and log of total Stream length

\subsubsection{Stream Length $(\mathrm{Lu})$}

The length of the stream channel is a dimensional property, which shows the size of the element of drainage lines. It is the total length of stream in a meticulous order. It is the most momentous hydrological feature of the basin which reveals surface runoff characteristics. Stream of comparatively smaller length are characteristics of areas with larger slopes and finer texture. Generally, the maximum length of the stream is found in first order streams and its length decreases as the increases of stream order. The numbers of stream of different orders in a basin were counted and their lengths are measured with the help of the software (Table 1). Correlation between logarithm of number of streams versus stream order and logarithm of length of stream versus stream order were measured figure 3 and 4 . 


\section{International Journal of Science and Research (IJSR) \\ ISSN (Online): 2319-7064}

Index Copernicus Value (2013): 6.14 | Impact Factor (2015): 6.391

$\mathrm{Nu} / \mathrm{A}$

(2)

\subsubsection{Mean stream length (Lsm)}

The mean length of a channel is a dimensional property and shows the characteristic size of drainage network components and its contributing basin surface [2].The mean stream length (Lsm) Mean stream length of a drainage basin is determined the following equation.

$$
\mathrm{Lsm}=\sum \mathrm{Lu} / \mathrm{Nu}
$$

[Where, $\sum \mathrm{Lu}$ is the total length of stream, $\mathrm{Nu}$ is the total number of stream of the basin] Here the mean stream length of $1^{\text {st }}$ order is $0.04,2^{\text {nd }}$ order is $0.12,3^{\text {rd }}$ order is $0.51,4^{\text {th }}$ order is $1.03,5^{\text {th }}$ order is 1.82 respectively (Table 1 ).

\subsubsection{Stream Length Ratio (RI)}

The Rl between streams of different orders in the study area show that there is a variation of $\mathrm{Rl}$ in basin (Table 1). The stream length ratio between the streams of different orders of the study area shows a change in the drainage basin. This change might be attributed due to the variation in slope and topography, indicating the late youth stage of geomorphic development in the streams of the study area (Table1).

\subsection{Aerial aspects of the drainage network}

Area (A) and perimeter (P) of the basin are the most significant parameters in quantitative morphology. Basin area is the hydrologically important because it directly affects the size of the storm hydrograph and the magnitudes of peak and mean runoff. The aerial aspect of the drainage basin such as Drainage density (Dd), Stream frequency(Fs), Drainage Texture (Rt), Form factor (f), Circularity ratio $(\mathrm{Rc})$, Elongation ratio $(\mathrm{Re})$, Length of overland flow $(\mathrm{Lg})$, Lemniscate $(\mathrm{k})$, Compactness Constant $(\mathrm{Cc})$, Constant channel maintenance(C), Infiltration Number(If) were calculated and results have been discuss in details.

\subsubsection{Basin Area (A)}

Basin area is the direct effect of the drainage development in a particular basin. The area of Daluaghat river basin is about $46.02 \mathrm{~km}^{2}$, Which indicates that rainwater will achieve the main channel more quickly, where the water has much further to travel.

\subsubsection{Drainage Density (Dd)}

Drainage density (Dd) expresses the convenience of spacing of channels, therefore providing a quantitative measure of the total length of stream channel for the entire basin. The total length of the stream of all orders divided by the area of the basin[4]. In general, the low drainage density leads to coarse texture while high drainage density leads to fine texture [2]. High drainage density is the resultant of weak and impermeable subsurface material and sparse vegetation and mountainous relief. The drainage density (D) of the basin is $0.29 \mathrm{~km}^{-} 1$ respectively.

\subsubsection{Stream frequency (Fs)}

Stream frequency of the basin may be defined as the ratio of the total numbers streams of all orders to the basin area [4]. It may express as -
Where, $\mathrm{Nu}$, Total numbers streams. A is Area of the basin. In the study area Fs is 3.36 respectively.

\subsubsection{Texture Ratio (Rt)}

Texture Ratio of the basin may be defined as ratio of total numbers of streams to the total perimeter of the basin. Texture ratio is a most significant influencing factor in the drainage morphometric analysis which is depends on the underlying lithology, infiltration capacity and relief aspect of the terrain. Smith [5] has classified drainage texture into five categories i.e. very coarse $(<2)$, Coarse (2-4), moderate (4$6)$, fine (6-8) and very fine (>8). In the study area texture ratio is 5.13 , which indicate moderate texture.

\subsubsection{Form factor}

Form Factor Ratio is the dimensionless ratio of the basin area to the square of basin length [4]. If the form factor value of would forever be greater than 0.78 for an absolutely circular basin. Long narrow basins have bigger lengths and hence smaller form factor. The value of form factor varies from 0 (highly elongated shape) to the unity i.e 1 (perfect circular shape). The Form Factor Ratio value of the Daluaghat river basin is 0.48 .

\subsubsection{Circularity Ratio (Rc)}

Circulatory ratio is the ratio of basin area to the area of circle having the same perimeter as the basin [6].

$$
4 \times \mathrm{A} / \mathrm{P}^{2}
$$

It is influenced more by the length, frequency and gradient of streams of various orders than slope conditions and drainage pattern of the basins (Strahler, 1957). Circulatory ratio of Daluaghat river basin is 0.63 .

\subsubsection{Elongation Ratio (Re)}

Elongation ratio is defined as the ratio of diameter of a circle of the same area as the basin to the maximum basin length [3].

$$
\operatorname{Re}=(2 \sqrt{A} / \pi) / \mathrm{Lb}
$$

It is the especially important index in the investigation of basin shape which helps to give an idea about hydrological characters of a drainage basin. The value of elongation ratio (Re) normally varies from 0.6 to 1.0 related with an extensive variety of climate and geology. Values close to 1.0 are typical of regions of very low relief whereas that of 0.6 to 0.8 are associated with high relief and steep ground slope (Strahler, 1964). These values can be classified into three categories, i.e. circular ( $>0.9)$, oval (09-0.8) and elongated (< $0.7)$. The Elongation ratio of the Daluaghat river basin is 0.78 which indicate basin is oval.

\subsubsection{Lemniscate $(\mathrm{k})$}

Chorely [7] state the lemniscate value to find out the slope of the basin. In the following equation to be used -

$$
\mathrm{k}=\mathrm{Lb}^{2} / 4 \mathrm{~A}
$$




\section{International Journal of Science and Research (IJSR) \\ ISSN (Online): 2319-7064}

Index Copernicus Value (2013): 6.14 | Impact Factor (2015): 6.391

Where, $\mathrm{Lb}$ is the basin length $(\mathrm{km})$ and $\mathrm{A}$ is the area of the basin $\left(\mathrm{km}^{2}\right)$. The lemniscate $(\mathrm{k})$ value for the basin is 0.52 respectively

\subsubsection{Compactness constant $(\mathrm{Cc})$}

Compactness constant is express as the ratio between the area of the basin and the perimeter of the basin [5]. Following formula is used.

$$
\mathrm{CC}=0.2821 \times \mathrm{P} / \mathrm{A} 0.5
$$

Where, $\mathrm{A}=$ Area of the basin, $\mathrm{Km}^{2}$. $\mathrm{P}=$ Basin perimeter, $\mathrm{Km}$ In present study area, the value of compactness constant is 1.00 .

\subsubsection{Length of overland flow (Lo)}

According to the Horton, [5]Length of overland flow mean the length of the runoff the rain water on the ground surface ahead of it gets determined into specific stream channels .This factor relates inversely to the average slope of the channel and is quite equal with the length of sheet flow to large degrees. The length of overland flow (Lo) roughly equals to half of the reciprocal of drainage density [5]. Lengths of overland flow in consequence calculated for Daluaghat basin is 1.73 respectively.

\subsubsection{Constant channel maintenance $(\mathrm{Ccm})$}

According to the Schumn [3] Constant channel maintenance mean the reciprocal of drainage density. It is expressed in sq $\mathrm{km}$. $/ \mathrm{km}$. while it represents the drainage to maintain one unit of channel length; consequently it is determined of basin erodibility. The value of basin is 3.44 respectively.

\subsubsection{Infiltration Number (If)}

Infiltration number is calculated by multiplying the value of drainage density (Dd) and stream frequency $(\mathrm{Fs})$. It is expressed as following formula

$$
\text { If }=\mathrm{D} \times \mathrm{Fs}
$$

Where, D is the Drainage density and Fs is the stream frequency. Accordingly higher the value of infiltration number greater the permeability of soil covers. In the present study Infiltration number is 0.97 respectively.

\subsection{Relief aspects of the drainage network.}

\subsubsection{Basin Relief $(\mathrm{H})$}

The difference between the maximum and minimum elevation of the basin is known as the basin relief. The contour value varies from $200 \mathrm{~m}$ to $357 \mathrm{~m}$. In the study Basin relief is 157 meters.

\subsubsection{Relief ratio $(\mathrm{Rh})$}

The relief ratio $(\mathrm{Rh})$ is the ratio between Relative relief of the basin and Basin length [3] (Table 1). According to him, there is direct correlation between the relief and channel gradient. The $\mathrm{Rh}$ is generally is increase with decreasing the drainage area and size of basin of a given drainage basin. In the present study Relief ratio is 15.58 . High values of $\mathrm{Rh}$ show steep slope and high relief while low values may indicate the lower degree of slope and small ridges.

\subsubsection{Ruggedness Number (RI)}

A dimensionless number that expresses the geometric characteristics of the drainage system; It is expressed as following formula

$$
\mathrm{H} \times \mathrm{Dd}
$$

Where, $\mathrm{H}$ is the Relative relief of basin and $\mathrm{Dd}$ is the drainage density of the basin. The ruggedness number of Daluaghat river basin is 4.52 respectively.

\section{Conclusion}

Quantitative investigation of drainage network create that the dendritic to sub dendritic drainage pattern is originated in the study area. Bifurcation ratio of Daluaghat river basin increases from $1_{\mathrm{st}}$ and 2 nd order but decreases in 4 th and 5 th order Stream because not exaggerated by structure control. In the study area texture ratio is 5.13, Drainage texture of the investigated watershed which indicates moderate texture. The morphometric parameter reveals to recognize different terrain parameters such as nature of the bedrock, infiltration capacity, runoff, etc. Related studies help in better understanding the landforms and their processes and drainage pattern demarcations for basin area planning and management.

\section{References}

[1] S. Singh, Geomorphology, Prayag Pustak Bhawan, Allahabad (2002).

[2] A.N. Strahler, Quantitative geomorphology of drainage basins and channel networks In. Handbook of Applied Hydrology, McGraw Hill Book Company, New York, Section 4II, 1964

[3] S.A Schumm, The evolution of drainage system and slopes in Badlands at Perth Amboy, New Jersey, Bulletin of Geological Society of America, 67,( 1956) pp 214-236.

[4] R.E Horton, Drainage basin characteristics, Trans. Amer. Geophys. U.14, (1932), pp 350-61.

[5] R.E. Horton, "Erosional development of streams and their drainage basins: hydrophysical approach to quantitative morphology", Bull. Geol. Soc. Amer.,5 1945,pp 275-370.

[6] K.G. Smith, , "Standards for grading texture of erosional topography”, Amer. Jour.Sci.,248, 1950 pp 655- 668

[7] V.C.Miller, "A quantitative geomorphic study of drainage basin characteristics in the Clinch Mountain area, Varginia and Tennessee", 1953, Project NR 389042,Tech. Rept.3.,Columbia University, Department of Geology, ONR, Geography Branch, New York.

[8] Chorley,R.J., Donald,E.G., Malm., and Pogorzelski,H.A., "A new standard for estimating drainage basin shape", Amer. Jour. Sci.,255, 1957, pp 138141.

[9] A Cilleux \& L Romani. Modern trends in geomorphological; vol 1 Ed by Sharma, Concept pub. New Delhi (1982) pp 9 - 19.

\section{Volume 5 Issue 7, July 2016




\section{International Journal of Science and Research (IJSR) \\ ISSN (Online): 2319-7064}

Index Copernicus Value (2013): 6.14 | Impact Factor (2015): 6.391

[10]R. J. Chorley, S. A Schumm,. And D.E., Sugden, Geomorphology, Methuen and Co. Ltd., London, (1985), pp 316-326.

[11] S L. Dingman FLUVIAL HYDRAULICS Copyright(C) 2009 by Oxford University Press.

[12]D. Knighton. Fluvial forms and processes A new perspective. Arnold publication (1998).

[13] L.B Leopold, M.G Wolman and J.P.Miller, Fluvial processes in geomorphology, Eurasia Publishing House, New Delhi. (1969).

[14] A. Miller, the skin of the earth. Methuen \& Co. Ltd., London (1953).

[15] M. Morisawa, Rivers-forms and process, Longman group, London, (1985), pp 54-56 and 70-73.

[16]P.K Sen., Geomorphological analysis of drainage basins, the University of Burdwan, Burdwan (1993).

[17]R.L Singh, India-a regional geography, National geographical society of India, Varanasi. (2008).

[18] M.A Summerfield, Global geomorphology, Prentice Hall, New Delhi, (1991), pp 208-212.

[19] S. Ghosh. Geomorphic land evaluation for sustainable use of lands resource in Puruliya district, W. B. Journal of landscape systems and ecological studies, 2012(June) vol.35 (1). pp. $263-274$.

[20] N.S Magesh and N. Chandrasekar. and J.Arab GIS model-based morphometric evaluation of Tamiraparani subbasin, Tirunelveli district, Tamil Nadu, India DOI 10.1007/s12517-012-0742- Geosci z (C) Saudi Society for Geosciences 2012.

[21] S.Dutta and S.Roy Determination of erosion surfaces and stages of evolution of Sangra drainage basin in
Giridih district, Jharkhand, India INTERNATIONAL JOURNAL OF GEOMATICS AND GEOSCIENCES. 2012.Volume 3, No 11,

[22] N K. Rao, S.P Latha , A.P. Kumar, and M.K. Hari, Morphometric Analysis of Gostani River Basin in Andhra Pradesh State, India Using Spatial Information Technology. INTERNATIONAL JOURNAL OF GEOMATICS AND GEOSCIENCES. 2010Volume 1, No 2.

[23]P.A Pisal, A.S.Yadav and A.B Chavan. 1986(Sept) Morphometric Analysis of Bhogavati River Basin, Kolhapur District, Maharashtra, India. IOSR Journal of Mechanical and Civil Engineering (IOSR-JMCE) ISSN: 2278- 1684, PP: 01-08, www.iosrjournals.org

[24]Census of India, Jharkhand State, Rural and Urban population total, (2001).

\section{Author Profile}

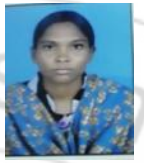

Sumitra Mandi received the B.A. Chandannagar College and M.A. degrees in Burdwan University in 2004 and 2006, respectively. At present she stayed in Birendranagar High School, Kaswara, Hooghly, and West Bengal, India.

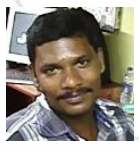

Kalicharan Soren received the B.A. Sri Gopal Banerjee College and M.A. degrees in Burdwan University in 1999 and 2001, respectively. At present she stayed in Lab.attendent, School of water resources Engg. Jadavpur University Kol - 700032 (W.B.) India

Table: 1 Linear Aspects of the morphometric attribute

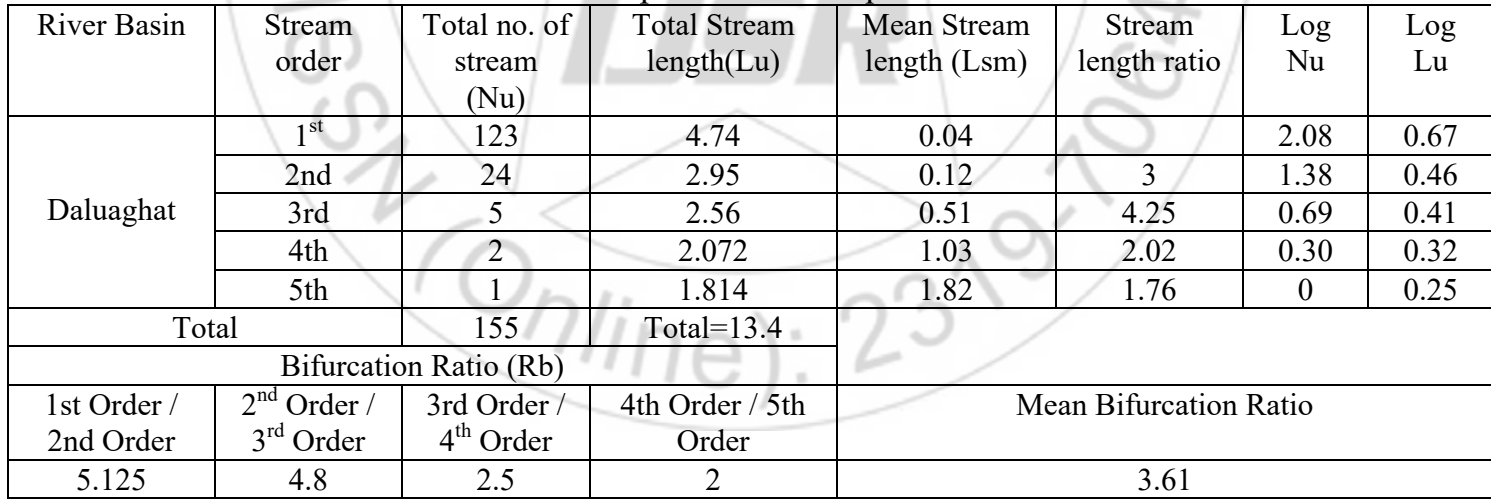

